This document was prepared in conjunction with work accomplished under Contract No. DE-AC09-96SR18500 with the U. S. Department of Energy.

\title{
DISCLAIMER
}

This report was prepared as an account of work sponsored by an agency of the United States Government. Neither the United States Government nor any agency thereof, nor any of their employees, nor any of their contractors, subcontractors or their employees, makes any warranty, express or implied, or assumes any legal liability or responsibility for the accuracy, completeness, or any third party's use or the results of such use of any information, apparatus, product, or process disclosed, or represents that its use would not infringe privately owned rights. Reference herein to any specific commercial product, process, or service by trade name, trademark, manufacturer, or otherwise, does not necessarily constitute or imply its endorsement, recommendation, or favoring by the United States Government or any agency thereof or its contractors or subcontractors. The views and opinions of authors expressed herein do not necessarily state or reflect those of the United States Government or any agency thereof. 
WSRC-RP-2005-01914

Revision \#0

Key Words: Gamma Assay Solid Waste Drum, Filter, Glovebox

Retention: permanent

\section{TASK TECHNICAL AND QUALITY ASSURANCE PLAN FOR GAMMA ASSAYS AT THE SRS SOLID WASTE MANAGEMENT FACILITIES}

Author(s) V. R. Casella, R. A. Sigg, and R. A. Dewberry

December 2005

Analytical Development Section

Savannah River National Laboratory

Aiken, SC 29808

Prepared for the U.S. Department of Energy Under Contract Number DEAC09-96SR18500
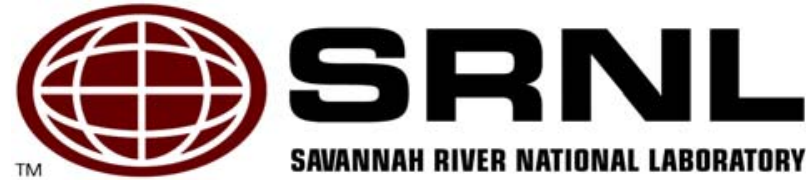

SAVANNAH RIVER NATIONAL LABORATORY 


\section{DISCLAIMER}

This report was prepared by Westinghouse Savannah River Company (WSRC) for the United States Department of Energy under Contract No. DE-AC09-96SR18500 and is an account of work performed under that contract. Neither the United States Department of Energy, nor WSRC, nor any of their employees makes any warranty, expressed or implied, or assumes any legal liability or responsibility for the accuracy, completeness, or usefulness, of any information, apparatus, or product or process disclosed herein or represents that its use will not infringe privately owned rights. Reference herein to any specific commercial product, process, or service by trademark, name, manufacturer or otherwise does not necessarily constitute or imply endorsement, recommendation, or favoring of same by WSRC or by the United States Government or any agency thereof. The views and opinions of the authors expressed herein do not necessarily state or reflect those of the United States Government or any agency thereof.

\section{Printed in the United States of America \\ Prepared For U.S. Department of Energy}


WSRC-RP-2005-01914

Revision \#0

REVIEWS AND APPROVALS

AUTHOR(S):

Titolasella

V. R. Canella, ADS, Task Leader
$12 / 21 / 05$

Date

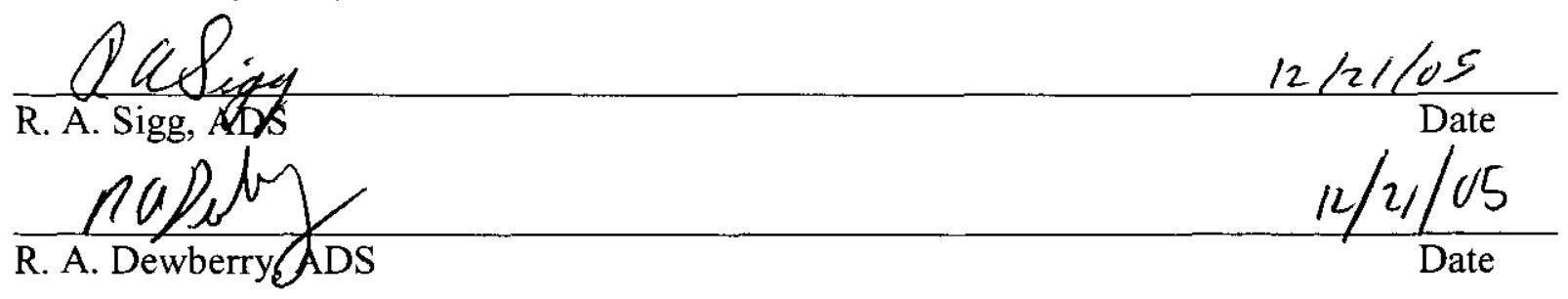

TECHNICAL REVIEWERS:

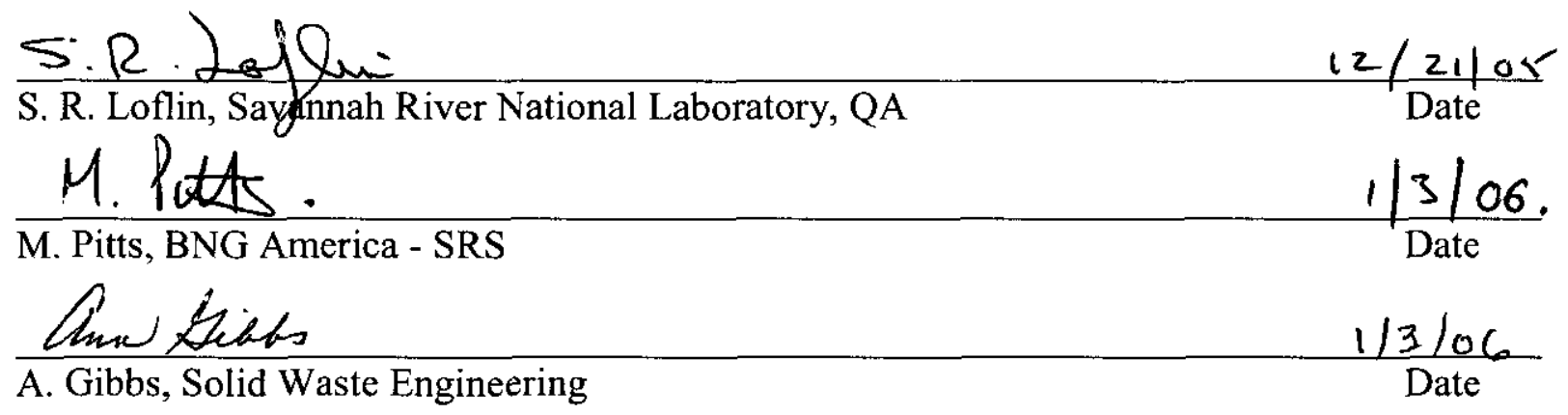

APPROVER

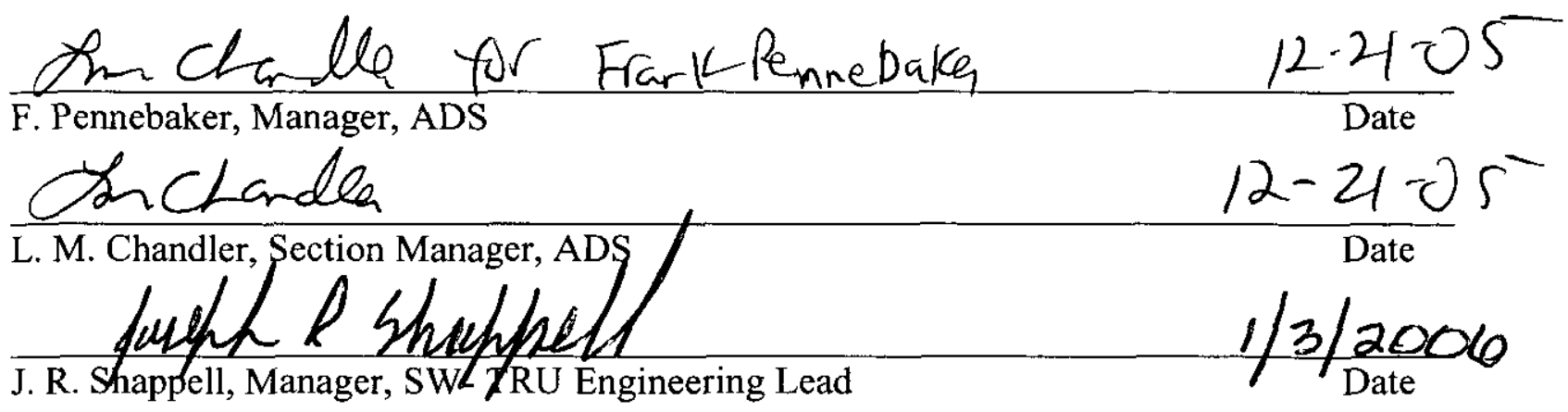




\section{TABLE OF CONTENTS}

1.0 INTRODUCTION

2.0 APPROACH - TASK DESCRIPTION 1

2.1 General Approach $\quad 1$

2.2 TRU Drums 2

2.3 Visual Examination (VE) Gloveboxes 3

2.4 HEPA Filters 4

2.5 Other Nonroutine Assays 4

2.6 Software 5

2.7 Measurement Uncertainties

3.0.DELIVERABLES AND ACCEPTANCE 6

4.0 RESPONSIBILITIES $\quad 6$

5.0 ACTIVITIES

6.0 DOCUMENTATION

7.0 RISK REVIEW

8.0 SCHEDULE

9.0 WASTE DISPOSAL 8

10.0 CONDUCT OF RESEARCH AND DEVELOPMENT CHECKLIST 8

11.0 DOCUMENT APPROVAL $\quad 8$

12.0 ANTICIPATED RECORDS 8

13.0 CONCLUSIONS $\quad 8$

14.0 ATTACHMENTS 9

15.0 REFERENCES 9

APPENDIX A- ADS TASK QUALITY PLAN CHECKLIST 9

\section{LIST OF FIGURES}

Figure 1. A germanium detector on an ORTEC IsoCart system. 2

Figure 2. ISOTOPIC's plot of output values as a function of gamma-ray energy. The points shown in blue are for various energies characteristic of Pu-239.

\section{LIST OF TABLES}

Table 1. Documents requiring management, customer, or CQF approval.

Table 2. Records anticipated for this task. Yes, no or as required (AR) is indicated. 


\section{LIST OF ACRONYMS}

SRNL - Savannah River National Laboratory

MCP - Measurement Control Plan

ADS - Analytical Development Section

TRU - Transuranic

MCA - Multichannel Analyzer

MDA - Minimum Detectable Activity

JCW - Job Control Waste

VE - Visual Examination

Ge - Germanium

CTF - Cognizant Technical Function

CQF - Cognizant Quality Function

SWAP - Solid Waste Area Project

SWMF - Solid Waste Management Facilities 


\subsection{INTRODUCTION AND BACKGROUND}

The Analytical Development Section (ADS) of the Savannah River National Laboratory (SRNL) provides assay services to the SRS SWMF. In recent years, Waste Management Area Projects has requested the Analytical Development Section (ADS) to nondestructively assay (NDA) a variety of items in order to determine the radioactive material contents of the items. These have included the Visual Examination (VE) Glove Box Train at TRU Pad 6, 55-gallon drums, and a heat exchanger. Additional NDA work is planned on HEPA filters, B-25 boxes, and the MRS glovebox train at Pad 19 in FY06.

ADS uses ORTEC's ISOTOPIC and Canberra's Genie 2K software to assist with the analysis of many of these items. Germanium detectors are used for the assays. This plan summarizes the methodologies used to calibrate a detector system, extend the calibration to other measurement geometries and reviews ISOTOPIC’s approach to dealing with gamma-ray attenuation for different geometries.

As stated, gamma assays are done for transuranic (TRU) drums, HEPA filters and gloveboxes, but assays of any sample configuration that can be modeled by ISOTOPIC can be performed, within certain limitations. This Technical Task and Quality Assurance Plan addresses the assays presently performed and considers other assays that might be requested in the future at the Solid Waste Management Facilities (SWMF) or at the 773-A F-Wing TRU Stabilization Gloveboxes.

\subsection{APPROACH - TASK DESCRIPTION}

\subsection{General Approach}

An Ortec portable ISOCART System (Figure 1) is used for the measurement. Detectors presently in use are a $20 \%$ germanium detector and a 0.5 -in lead shield or a $40 \%$ germanium detector and a 0.625 -in lead shield. Other calibrated detectors may be used. Canberra Inspector electronics (high voltage power supply, amplifier and multichannel analyzer) or another multichannel analyzer (MCA) system can be used to acquire the spectra. Canberra Genie 2K Version 2.1A and Ortec Isotopic 2.0.6. software have been used for MCA control, spectral analysis, drum calibration and attenuation corrections. The collimated Ge detector is positioned on the ISOCART stand at a measured distance from the object being assayed, and a gamma ray spectrum is collected. The detector system's energy calibration is set up using Cs-137 and Co-60 standards at SRNL, and this calibration is confirmed on location, possibly using the relatively high Cs-137 background.

The calibration of the detectors used for this method is described in technical report "Nondestructive Assay Efficiency Calibration of Ge Detectors for the Ortec Isotopic Method”, WSRC-TR-2005-00431. Ge detectors are calibrated using a Pu-239 source and a NIST-traceable mixed gamma-ray standard. The point source is positioned on an on-axis position 12 inches from the face of each high purity germanium detector. Gamma-ray spectra are collected sufficiently long in order to obtain good counting statistics relative to the accuracy of the standard. The mixed gamma source provides detector efficiency data as a function of energy covering an energy range that encompasses all gamma rays of Pu-238, 239, 240, 241. The gamma ray library includes photon per decay data for each gamma ray that is characteristic of Pu-239 and other TRU nuclides. Data analysis uses two commercial software packages, specifically:

- Canberra Industries “Genie 2000” software for determining peak energies and areas in the spectrum, and corrections from the detector calibration. 
- Ametek/ Ortec "ISOTOPIC" software reads the Genie 2000 results files and it applies corrections to account for differences in measurement geometry and attenuation between the calibration source and the $\mathrm{Pu}-239$ source.

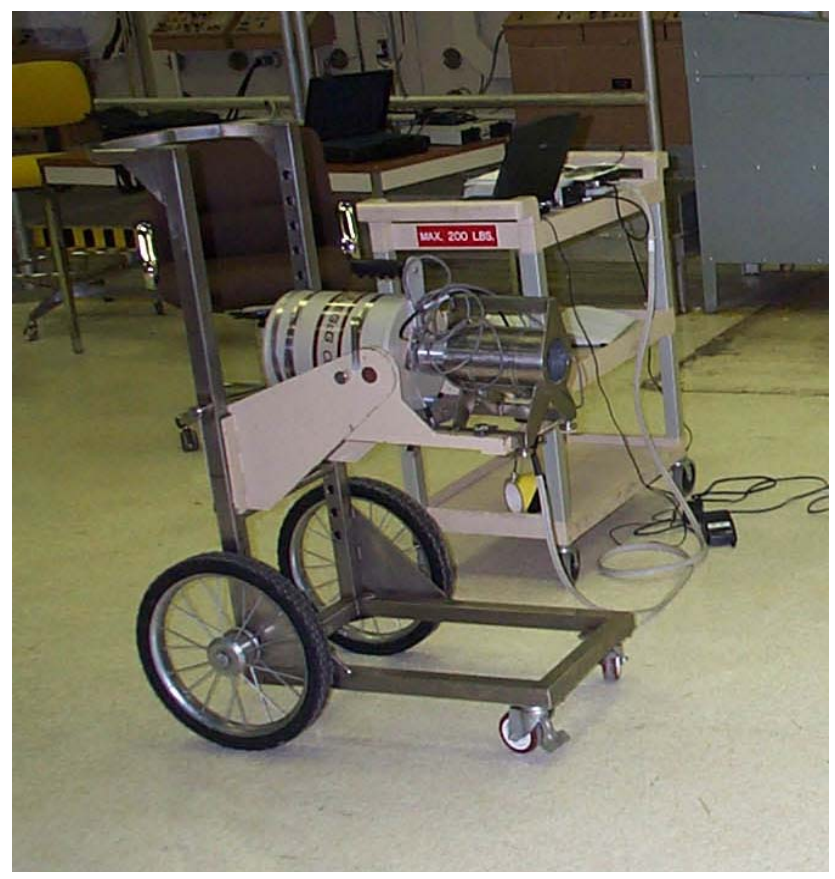

Figure 1. A high-purity germanium detector on an ORTEC IsoCart system.

This data analysis approach yielded results that were consistent to within $2 \%$ of the Material Control \& Accountability (MC\&A) value for a known Pu-239 source. Verification of the system calibration and operation for data acceptance is performed before and after the assays and compared to the previously known value, as described in report SRNL-ADS-2005-00673, "Measurement Control Plan for ADS Nondestructive Analysis." As stated in this report, "each reported result is independently technically reviewed."

\subsection{TRU Drums}

Drums at the SWMF that contain Job Control Waste (JCW) are analyzed for TRU nuclides by measuring the Pu-239 concentration and using the appropriate waste stream fingerprint for each drum to calculate the concentrations of other nuclides in the drum. If the Pu-239 is not detected for the count time used (usually one hour), the minimum detectable activity (MDA) is used for the determination. Some of the drums are low-level waste and, therefore, contain TRU nuclides below the TRU limit (100 nCi/gram). If the MDA is used, the assays of the drums may be either TRU or low-level waste. The percent Pu-238 or 239 in the waste stream is an important factor in determining whether or not the drum contains TRU waste. The waste stream, Engineering Calculation Note number for the waste stream, and whether a measured value or MDA was used for the calculated activities are reported. For other assays, the measurement of another nuclide, rather than $\mathrm{Pu}$-239, (such as $\mathrm{Pu}-238$ ) can be used for scaling the other nuclides present in the drum. Also, if the nuclides requested can be measured directly (without scaling), particularly if the waste stream fingerprint is unknown, then drums may be assayed in this way.

The Ortec portable ISOCART System previously described is used for the measurements The collimated Ge detector is positioned on the ISOCART stand, usually at a distance of 10 inches to 36 inches from the drum but can be positioned at a much farther distance if the drum contains a great deal of radioactivity. 
The drum is put on a drum rotator to minimize density differences in the drum contents. The 55-gallon drum is considered a standard configuration in ISOTOPIC, so all of the container dimensions are already entered, and only the drum weight, standoff distance, collimator, and waste type (combustible rather than high density material) must be entered into the program. Results are obtained and input into Excel spreadsheets which have the distributions of TRU nuclides based on the known waste stream per the Engineering Calculation Note.

\subsection{Visual Examination (VE) Gloveboxes}

The Visual Examination gloveboxes (TRU Pad 6 and TRU Pad 19) are used to remediate transuranic waste (TRU) drums by removing noncompliant items before the drums undergo further characterization in preparation for shipment to the Waste Isolation Pilot Plant (WIPP). Maintaining the flow of drums through the remediation process is critical to the program's 7-days-per-week operation. For the TRU Pad 19 operation, facility operators will assume that $90 \%$ of the Pu inventory in a drum leaves the glovebox following remediation, i.e. 10\% remains in the glovebox and pre-filter train. Upon request of Solid Waste Engineering, ADS will perform hold up measurements in order to confirm that this $10 \%$ hold up assumption is conservative. A similar operation is being set up at the 773-A F-Wing TRU Stabilization Glovebox Train, and the methodologies described in this plan also apply to the 773-A gloveboxes. Note that previous hold up measurements performed on the Pad 6 glovebox showed that actual holdup was much less than the conservative $10 \%$ assumption made for the initial operation of the facility.

High Cs-137 backgrounds in the VE glovebox area preclude the use of a sodium iodide spectrometer, so a germanium (Ge) detector, having superior resolution, is used. Pu-239 is observable only when the detector views the glovebox from the front (plastic window side) of the box. The plastic window only minimally attenuates the Pu-239 gamma rays. The facility layout and the size of the detector with its shield and stand permits a small spacing between the detector and glovebox. Since "far field" measurements are not possible, the glovebox to be assayed will be divided into sections and the results for each section will be combined. Each section is treated as a plane source with all of the activity distributed on the back wall of the box. This approach yields conservatively high estimates of Pu content.

The Ge detector was calibrated using a Pu-239 source and a NIST-traceable mixed gamma-ray standard. For the VE facility on Pad 6, collimated Ge measurement data are collected by placing the shield and collimated detector on a stand that positions the detector:

- 10 inches above the glovebox floor,

- 7.25 inches from the glovebox's plastic window,

- Near the horizontal center of each of the four glovebox sections.

Additional spectra are taken with the detector aimed at the lower left hand HEPA filter in the glovebox furthest to the right, and aimed towards the back left corner of the leftmost glovebox section. These detector positions are typical; however, other detector heights and distances may be used.

The material is assumed to be on the back wall of the glovebox to give a conservatively high result. The detector arrangement does not allow precise mapping of the material, and the detector is too close to treat the box as a far-field measurement. Therefore, this conservative estimate is employed. Similar conservative estimates will be employed for assays at other glovebox locations.

For Pad 6, the program ISOTOPIC determined that the geometry correction factor to account for differences between the mixed gamma-ray standard and the back wall is 9.17. The attenuation correction for the glovebox window is 1.08 while the attenuation corrections for the matrix varied from 1.00 to 1.27. This program uses gamma rays at different energies to determine the matrix correction. Since gamma 
rays at lower energies are more easily attenuated, the plutonium content is given for each gamma ray energy. In order to achieve the optimal positioning of the detector assembly, a mechanical engineer has designed a detector positioning apparatus to be used for Pad 19 measurements.

Measuring Pu-238 in the glovebox train is somewhat less accurate than determining Pu-239. Since the gamma rays measured for Pu-238 are lower energy than gamma rays for Pu-239, the attenuation correction for Pu-238 is less certain. Also, the background is higher in the Pu-238 region of the spectrum and the $\mathrm{Pu}-238$ emission rate is lower than for Pu-239 making the measurement less accurate. Results in grams are reported for the nuclides requested by Solid Waste Engineering. These are typically: Pu-239, $\mathrm{Pu}-241, \mathrm{~Np}-237$ (including its daughter Pa-233) and Pu-238 if detected. Since Pu-238 is a likely component of the hold-up, a Limit of Detection value can be reported in the event that it is not measured directly. Cs-137 and Co-60 may also be detected but are not reported since they do not contribute to the $\mathrm{Pu}-239$ Fissile Gram Equivalent or Pu-239 Equivalent Curies.

The measured gram values for these glove box trains are conservative estimates due to the geometry assumptions that were made for the measurements. For further conservatism, the measured values are doubled before reporting.

\subsection{HEPA Filters}

HEPA filters are also assayed by the same methodology given in this plan. These filters can be assayed directly (wrapped in plastic or other light weight material to prevent spread of contamination), contained in a 55-gallon drum, or located within the filter housing. Assaying the filter(s) directly provides the least uncertainty from gamma attenuation corrections. For the MRS glovebox on Pad 19, the HEPA is contained in a stainless steel housing, and attenuation corrections must be applied for both the filter and the housing. Since the HEPA filter is not a standard configuration in ISOTOPIC software, the dimensions and matrices of the filter and housing are used to configure each measurement geometry.

\subsection{Other (Nonroutine) Assays}

Although assays of drums, gloveboxes and HEPA filters are discussed in detail in this plan, this assay methodology can be used for essentially any object that can be configured in ISOTOPIC software. In general, as the detector-to-object distance increases and as the density of the object decreases (reducing gamma attenuation), the accuracy of the assay is increased. If the detector-to-object distance is very large and a "far-field" approximation is justified, then the object can be considered a point source, and the assay is essentially independent of the sample effects, such as homogeneity and detector positioning.

Measurements are performed in such a way that the object being assayed is within the field-of-view of the detector and collimator assembly. However, in special cases, several parts of the object may be assayed and the total activity measured is the sum of each part. It is always desirable to rotate the object that is being assayed for volumetrically contaminated material, but cannot always be done if the container is fixed or too heavy.

Transmission measurements may be used to determine attenuation corrections, rather than using ISOTOPIC for this purpose. Transmission measurements may be preferred in certain circumstances, especially if the contents or matrix of the object being measured are completely unknown. Transmission assays are usually "far-field" assays that use a standard radioactive source(s) that is counted with and without the object being assayed to determine attenuation effects. Several transmission measurements are performed at different regions (top, middle, bottom) of the object being assayed. 


\subsection{Software}

The computer programs used for the assays described in this plan are executable code only and do not meet the requirements of "assay software" as defined in the Measurement Control Plan (MCP), SRNLADS-2005-00673. The MCP states that "Assay Software for the purposes of this document is defined as the source code only and can only be changed by the vendor." Therefore, the configuration control of the assay software is the responsibility of the vendor.

WSRC Manual 1Q, Procedure 20-1 states: “This procedure applies to all software and firmware except: Software which is part of measuring and test equipment (MT\&E) or measuring systems and equipment (MS\&E) where the equipment is verified periodically as part of a calibration program compliant with Procedure Manual 1Q, Quality Assurance Manual, Procedure 12-1, "Control of Measuring and Test Equipment" or Procedure Manual 1Q, Procedure 2-7, "QA Program Requirements for Analytical Measurement Systems, respectively.”

As previously stated, results are input into Excel spreadsheets which have the distributions of TRU nuclides based on the known waste stream per the Engineering Calculation Note. Work instruction ADSWI00023 list requirements for spreadsheet quality control.

\subsection{Measurement Uncertainties}

The total measurement uncertainty, consisting of counting statistics errors, geometry correction factors, attenuation corrections, spectral stripping and nuclide data uncertainties, is determined by ISOTOPIC for each assay. In general, even with excellent counting statistics, the overall uncertainties for these types of measurements range from about 10 to 50 percent. Richard Hagenauer, developer of ISOTOPIC, estimates that the uncertainty for typical 55-gallon drum TRU waste assay is to be about $15 \%$ (private communication). An estimate of the measurement uncertainty for each configuration needs to be estimated for a typical measurement, but will vary based on counting statistics errors, attenuation corrections, and other sample dependent parameters.

ORTEC's ISOTOPIC software calculates geometry correction factors to apply the point-source calibration to assays of objects having other shapes. The software also determines attenuation corrections from knowledge of the container materials, matrix composition and density, and percent composition of high atomic number materials ( $\mathrm{U}$ or $\mathrm{Pu}$ ). Many radionuclides emit gamma-rays at several energies and, if all corrections are made appropriately, analysis of the data for the different energies should give the same value for the number of Curies or grams of nuclear material in the object. A unique and important feature of ISOTOPIC is that it provides a graphical display of these results for each gamma-ray from a radionuclide (Figure 2). This visual interface is useful in determining whether the information that was applied in calculating attenuation factors was correct. ISOTOPIC goes further by providing slide bars for the visual interface. These allow the parameters used to be adjusted for each contributor to attenuation until the results match. That is, each gamma-ray gives close to the same answer (possibly within counting uncertainties) for the activity or mass of the radionuclide. 


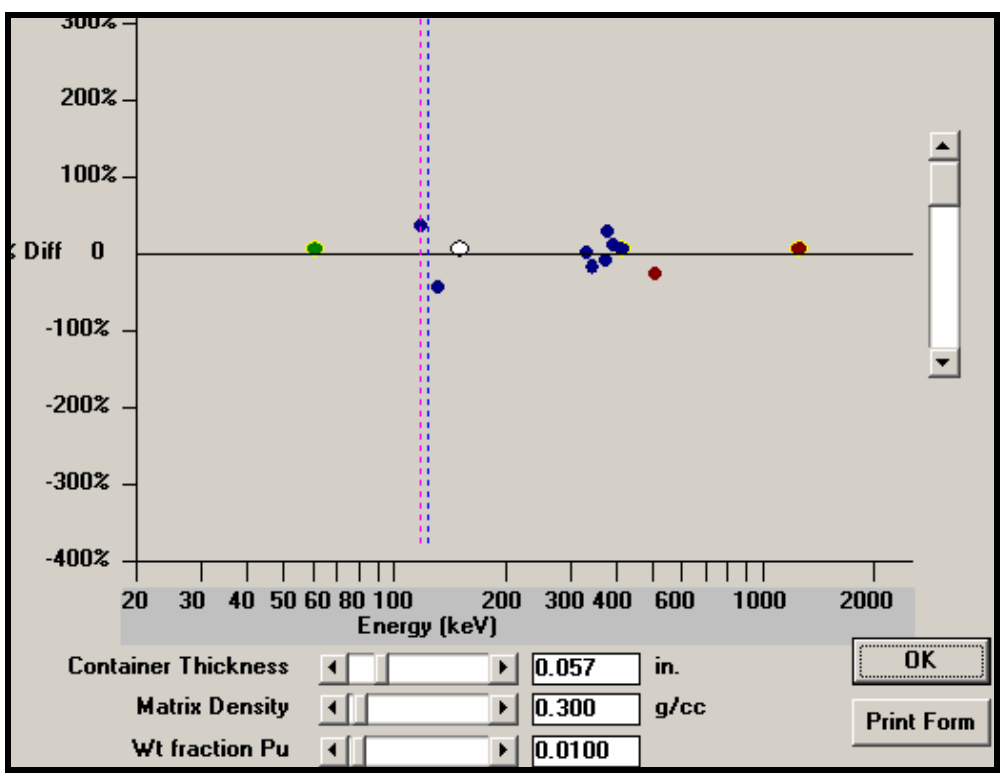

Figure 2. ISOTOPIC's plot of output values as a function of gamma-ray energy. The points shown in blue are for various energies characteristic of Pu-239.

While the program comes with several predefined descriptions of waste containers, it provides a relatively simple user interface for describing other objects. SRNL has used this method for holdup measurements at the TRU Pad 6 VE glovebox train, assays of wastes in 55-gallon drums, and to a heat exchanger.

\subsection{DELIVERABLES AND ACCEPTANCE}

The primary deliverable is to provide portable gamma assay services to the Solid Waste Area Project (SWAP) for drums, gloveboxes, HEPA filters, and any other item(s) requested. The performance of this task is controlled by an SRNL developed Measurement Control Program (MCP) per WSRC 1Q, Procedure 2-7. The primary nuclides of interest are $\mathrm{Pu}-239$ and $\mathrm{Pu}-238$. After a series of measurements are completed, a formal report will be submitted to the Solid Waste Engineering Cognizant Technical Function (CTF) for review and concurrence. The report will include the results of the measurement by nuclide quantified, all selectable parameters that are adjustable by the operator, and a discussion of the uncertainty of the measurement in terms of instrument uncertainty, potential matrix effects, and any shielding, filtering or orientation impacts. The report will document compliance with the Measurement Control Program, and will be submitted to the Solid Waste Engineering CTF nominally within three business days.

\subsection{RESPONSIBILTIES}

Personnel in the Analytical Development Section will:

- Calibrate the assay system,

- Obtain check sources to confirm stable detector performance,

- Keep assay equipment in operable condition,

- $\quad$ Provide assay reports to Solid Waste Engineering CTF,

- $\quad$ Set up system for nonroutine assays.

- Provide documentation as required by SRS procedures (SQAP, TTQAP, etc.) 
Personnel in the SWMF or other customers will:

- Schedule, coordinate and update task activities,

- Provide review and approval of the technical task and quality assurance plan.

- Solid Waste Engineering CTF will review assay reports.

Personnel in SRNL Quality Assurance will:

- Review and approve the task technical and quality assurance plan,

- Provide guidance and oversight for this task as needed.

\subsection{ACTIVITIES}

Provide portable gamma assay services for drums, gloveboxes, HEPA filters and other items, as requested.

\subsection{DOCUMENTATION}

All pertinent calibrations, results, and calculations that are not saved on computer media as part of assay documentation will be documented in ADS notebooks in accordance with SRNL L1 Manual, Procedure 7.16. Assay results will be documented in reports as described in this plan and the MCP. MSE files are kept in notebooks or in a file as individual records as described in the applicable requirements of WSRC 1Q, Procedure 2-7.

The following items shall be designated records for this program:

- This task technical and quality assurance plan or any revisions, as may apply to a specific program,

- Controlled laboratory notebook(s),

- Interim memos,

- Final report and supporting documentation as determined by the task leader.

Any revisions to this task technical and quality assurance plan require the same approval as the original.

\subsection{RISK REVIEW}

The programmatic risks and mitigation are given below:

- Equipment failure - other equivalent (calibrated) equipment is available for short-term use until the failed items are repaired.

- Personnel availability - primary and secondary researchers will be identified to preclude insufficient support.

- Facility outage - could result in short delays.

\subsection{SCHEDULE}

The MCP and this Technical Task and Quality Assurance plan will be submitted to SWAP personnel for review by December 1, 2005. After approvals are received, work may commence per the customer work schedule. 


\subsection{WASTE DISPOSAL}

No liquid wastes are expected to be generated in this effort. Sealed sources used for calibration may eventually be categorized as waste; existing site source control procedures will be followed for their disposition.

\subsection{CONDUCT OF REASEARCH AND DEVELOPMENT CHECKLIST}

Per the Conduct of R\&R, a Conduct of R\&D Hazards Screening Checklist must be completed. This activity is similar to other gamma-ray detector efforts, and potential hazards are well understood. A complete Conduct of R\&D Hazards Screening Checklist (ADS Job Sheet SRNL-2005-0088) has been prepared, and the Hazards Screening Checklist will be periodically reviewed at the principal investigator's discretion to verify that the Plan remains sufficient for analysis activities associated with this program.

\subsection{DOCUMENT APPROVAL}

Table 1. Documents requiring management, customer, or CQF approval.

\begin{tabular}{|c|c|c|c|c|}
\hline \multirow[t]{2}{*}{ Document } & Management & Customer & \multicolumn{2}{|c|}{ CQF } \\
\hline & Yes $\quad$ No & Yes $\quad$ No & Yes & No \\
\hline Technical and QA Plan & $X$ & $X$ & $X$ & \\
\hline Task Technical Reports & $\mathrm{X}$ & $\mathrm{X}$ & & $\mathrm{X}$ \\
\hline Final Report (if applicable) & $\mathrm{X}$ & $\mathrm{X}$ & & $\mathrm{X}$ \\
\hline
\end{tabular}

\subsection{ANTICIPATED RECORDS}

Table 2. Records anticipated for this task. Yes, no or as required (AR) is indicated.

\begin{tabular}{|c|c|c|l|}
\hline Yes & No & AR & \multicolumn{1}{c|}{ Decription } \\
\hline $\mathrm{X}$ & & & Task Technical \& QA Plan \\
\hline & $\mathrm{X}$ & & Technical Notebooks \\
\hline & & $\mathrm{X}$ & Task Technical Reports \\
\hline & $\mathrm{X}$ & & Data Qualification Reports \\
\hline & & $\mathrm{X}$ & Supporting Documentation \\
\hline $\mathrm{X}$ & & & Final Report (if applicable) \\
\hline
\end{tabular}

\subsection{CONCLUSIONS}

This Technical Task and Quality Assurance Plan meets the requirements set forth in Technical Task Request SWI-TTR-2005-003, "Provide portable gamma assay services for drums, gloveboxes and HEPA filters, as requested," and meets the requirements for ADS gamma assay services using Ortec's ISOTOPIC, Canberra's Genie 2K, or other similar gamma assay programs.

An Ortec portable ISOCART stand is used to hold the germanium (Ge) detector with a collimated shield. Electronics (high voltage power supply, amplifier and multichannel analyzer (MCA)) from Ortec, Canberra, or others can be used to acquire the spectra. Canberra Genie 2K Version 2.1A and Ortec Isotopic 2.0.6. software have been used for MCA control, spectral analysis, calibration, and attenuation corrections. The germanium detector efficiency calibration (counts/photon emission) over the required 
gamma-ray energy range is determined using NIST traceable reference materials and documented in a technical report. The energy calibration (keV/MCA channel) is set in the laboratory using the same standards and confirmed in the field before assays begin.

In the field, the collimated germanium detector is positioned on the ISOCART stand or on another detector arrangement at a measured distance from the object being assayed, and a gamma-ray spectrum is collected. Experienced scientists oversee the setup and accumulation of data to prevent errors in the field. Assay results are peer reviewed and reported to the customer in a technical report which includes details of the analysis. The methodology described in this plan is used for drums, gloveboxes, HEPA filters and any other object that ADS scientists can model with the Ortec software.

\subsection{ATTACHMENTS}

Not applicable.

\subsection{REFERENCES}

1. Savannah River Technology Center Administrative Plan for Employee Training Plans, SRTCAPEP.X0100, Rev.0 (2004).

2. ISOTOPIC Version 2.0.6, Ametek/ ORTEC Corp.

3. Genie2K Version 2.1A, Canberra Industries

4. R.A. Sigg, F.S. Moore, , Solid Waste TRU Pad 6 Glovebox Holdup Assay, SRTC-ADS-2003-0561 (2003).

5. Ray A. Dewberry and Vito R. Casella, Assay Results for JCW Drums 8/05, SRNL-ADS-2005-0498 (2005).

6. Frank S. Moore and Saleem Salaymeh, Traditional and Model Based Assay of Irregular Geometry Items, WSRC-TR-2005-00070 (2005).

7. QA Program Requirements for Analytical Measurement Systems, WSRC 1Q, Procedure 2-7, Rev.6 (2005).

8. Measurement Control Plan for ADS Nondestructive Analysis (U), SRNL-ADS-2005-00673 (2005).

9. Private communication, Richard Hagenhauer (2005).

10. Provide portable gamma assay services for drums, gloveboxes and HEPA filters, as requested, SWITTR-2005-003, (2005).

11. Spreadsheet Quality Control for Analytical Development Section(ADS), ADS-WI00023 (2004). 


\section{APPENDIX A. ADS TASK QUALITY ASSURANCE PLAN CHECKLIST}

Task Technical Plan No: WSRC-RP-2005-001914 Task Title: Gamma Assays at the SRS SWMF. Listed below are the sections of WSRC $1 \mathrm{Q}$. Check WSRC $1 \mathrm{Q}$ sections applicable to the task. Also check procedures ADS implements to control the task. This checklist identifies only procedures used to control task activities performed by ADS. (Form Revised 12/18/2003)

\begin{tabular}{|c|c|c|c|}
\hline WSRC 1Q Section & $\begin{array}{l}\text { Applies } \\
\text { To Task }\end{array}$ & QA Procedures Implemented & $\begin{array}{l}\text { Procedure } \\
\text { Used }\end{array}$ \\
\hline \multirow[t]{2}{*}{ Organization } & \multirow[t]{2}{*}{$\mathrm{X}$} & $\begin{array}{l}\text { 1Q, QAP 1-1, Organization } \\
\text { L1, 1.02, SRNL Organization }\end{array}$ & $\begin{array}{l}\mathrm{X} \\
\mathrm{X} \\
\end{array}$ \\
\hline & & 1Q, QAP 1-2, Stop Work & $\mathrm{X}$ \\
\hline \multirow[t]{5}{*}{ QA Program } & \multirow[t]{5}{*}{$\mathrm{X}$} & 1Q, QAP 2-1, Quality Assurance Program* & \multirow{2}{*}{$\begin{array}{l}X \\
X\end{array}$} \\
\hline & & $\begin{array}{l}\text { 1Q, QAP 2-2, Personnel Training \& Qual. } \\
\text { L1, 1.32, Read and Sign }\end{array}$ & \\
\hline & & $\begin{array}{l}\text { 1Q, QAP 2-3, Control of R\&D Activities* } \\
\mathrm{L} 1,7.10 \text {, Control of Technical Work }\end{array}$ & $\begin{array}{l}X \\
X\end{array}$ \\
\hline & & L1, 7.16, Laboratory Notebooks and Logbooks & $\mathrm{X}$ \\
\hline & & $\begin{array}{l}\text { 1Q, QAP 2-4, Auditor/Lead Auditor Qual. \& Cert. } \\
\text { 1Q, QAP 2-5, Qual. \& Cert. of Independent Insp. } \\
\text { Personnel } \\
\text { 1Q, QAP 2-7 QA Program Req. for Analytical } \\
\text { Measurement Systems }\end{array}$ & NA \\
\hline Design Control & & $\begin{array}{l}\text { 1Q, QAP 3-1, Design Control } \\
\mathrm{L} 1,7.10 \text {, Control of Technical Work }\end{array}$ & NA \\
\hline $\begin{array}{l}\text { Procurement } \\
\text { Document } \\
\text { Control }\end{array}$ & $\mathrm{X}$ & $\begin{array}{l}\text { 1Q, QAP 4-1, Procurement Document Control } \\
\text { E7, 3.10, Determination of Quality Requirements for } \\
\text { Procured Items } \\
7 B, 3 E \text { (for reference only) }\end{array}$ & $\mathrm{X}$ \\
\hline $\begin{array}{l}\text { Instructions, } \\
\text { Procedures } \\
\text { and Drawings }\end{array}$ & $\mathrm{X}$ & $\begin{array}{l}\text { 1Q, QAP 5-1, Instructions, Procedures, \& Drawings } \\
\text { E7, 2.30, Drawings } \\
\text { L1, 1.01, SRNL Procedure Administration }\end{array}$ & $\mathrm{X}$ \\
\hline Document Control & $\mathrm{X}$ & $\begin{array}{l}\text { 1Q, QAP 6-1, Document Control } \\
\text { 1B, MRP 3.32 }\end{array}$ & $\begin{array}{l}\mathrm{X} \\
\mathrm{X}\end{array}$ \\
\hline $\begin{array}{l}\text { Control of Purchased } \\
\text { Items and Services }\end{array}$ & $\mathrm{X}$ & $\begin{array}{l}\text { 1Q, QAP 7-2, Control of Purchased Items \& } \\
\text { Services } \\
7 B \& 3 E \text { (for reference only) }\end{array}$ & $\begin{array}{l}\mathrm{X} \\
\mathrm{X}\end{array}$ \\
\hline & & $\begin{array}{l}\text { 1Q, QAP 7-3, Com. Grade Item Dedication } \\
\text { E7, 3.46, Replacement Item Evaluation/Com- } \\
\text { mercial Grade Item Dedication }\end{array}$ & \\
\hline $\begin{array}{l}\text { Identification and } \\
\text { Control of Items }\end{array}$ & $\mathrm{X}$ & 1Q, QAP 8-1, ID and Control of Items* & $\mathrm{X}$ \\
\hline \multirow[t]{4}{*}{ Control of Processes } & & 1Q, QAP 9-1, Control of Processes & NA \\
\hline & & 1Q, QAP 9-2, Control of Nondestructive Exam. & NA \\
\hline & & 1Q, QAP 9-3, Control of Welding \& Joining Proc. & NA \\
\hline & & $\begin{array}{l}\text { 1Q, QAP 9-4, Work Processes } \\
\text { 1Y, 8.20, Work Control Procedure }\end{array}$ & NA \\
\hline Inspection & & $\begin{array}{l}\text { 1Q, QAP 10-1, Inspection \& Verification } \\
\text { L1, 8.10, Inspection }\end{array}$ & NA \\
\hline Test Control & & $\begin{array}{l}\text { 1Q, QAP } 11-1 \text {, Test Control (applies to ADS only for } \\
\text { acceptance testing; R\&D test activities are controlled } \\
\text { by } 1 Q, \text { QAP } 2-3 \text { ) }\end{array}$ & NA \\
\hline $\begin{array}{l}\text { Control of Measuring } \\
\& \text { Test Equipment }\end{array}$ & $\mathrm{X}$ & $\begin{array}{l}\text { 1Q, QAP 12-1, Control of Measuring \&Test } \\
\text { Equipment }\end{array}$ & $\mathrm{X}$ \\
\hline
\end{tabular}


WSRC-RP-2005-01914

Revision \#0

\begin{tabular}{|c|c|c|c|}
\hline WSRC 1Q Section & $\begin{array}{l}\text { Applies } \\
\text { To Task }\end{array}$ & QA Procedures Implemented & $\begin{array}{l}\text { Procedure } \\
\text { Used }\end{array}$ \\
\hline & & $\begin{array}{l}\text { 1Q, QAP 12-2, Control of Installed Process } \\
\text { Instrumentation }\end{array}$ & \\
\hline & & $\begin{array}{l}\text { 1Q, QAP 12-3, Control \& Calibration of Radiation } \\
\text { Monitoring Equipment }\end{array}$ & \\
\hline $\begin{array}{l}\text { Packaging, Handling, } \\
\text { Shipping \& Storage }\end{array}$ & & 1Q, QAP 13-1, Pkg., Handling, Ship. \& Storage* & NA \\
\hline $\begin{array}{l}\text { Inspection, Test, and } \\
\text { Operating Status }\end{array}$ & & 1Q, QAP 14-1, Inspection, Test, \& Operating Status* & NA \\
\hline $\begin{array}{l}\text { Control of Noncon- } \\
\text { forming Items \& } \\
\text { Activities }\end{array}$ & $\mathrm{X}$ & 1Q, QAP 15-1, Control of Nonconforming Items* & $\mathrm{X}$ \\
\hline $\begin{array}{l}\text { Corrective Action } \\
\text { System }\end{array}$ & $\bar{X}$ & $\begin{array}{l}\text { 1Q, QAP 16-3 Corrective Action Program } \\
\text { 1.01, MP 5.35, Corrective Action Program } \\
\text { 1B, MRP 4.23, Site Tracking, Analysis and Reporting }\end{array}$ & $\begin{array}{l}\mathrm{X} \\
\mathrm{X} \\
\mathrm{X}\end{array}$ \\
\hline QA Records & $\mathrm{X}$ & $\begin{array}{l}\text { 1Q, QAP 17-1, QA Records Management* } \\
\text { L1, 7.16, Laboratory Notebooks and Logbooks }\end{array}$ & $\begin{array}{l}X \\
X\end{array}$ \\
\hline \multirow[t]{5}{*}{ Audits } & \multirow[t]{5}{*}{$\mathrm{X}$} & 1Q, QAP 18-2, QA Surveillance & $\mathrm{X}$ \\
\hline & & 1Q, QAP 18-3, QA External Audits & \\
\hline & & $\begin{array}{l}\text { 1Q, QAP 18-4, Management Assessments } \\
\text { 12Q, Assessment Manual }\end{array}$ & \multirow[t]{3}{*}{$\mathrm{X}$} \\
\hline & & 1Q, QAP 18-6, Quality Assurance Internal Audits & \\
\hline & & $\begin{array}{l}\text { 1Q, QAP 18-7, Quality Assurance Supplier } \\
\text { Surveillance }\end{array}$ & \\
\hline Quality Improvement & & 1Q, QAP 19-2, Quality Improvement* & \\
\hline $\begin{array}{l}\text { Software Quality } \\
\text { Assurance }\end{array}$ & $\mathrm{X}$ & $\begin{array}{l}\text { 1Q, QAP 20-1, Software QA } \\
\text { L1, 8.20, Software Management \& QA }\end{array}$ & $\begin{array}{l}\mathrm{X} \\
\mathrm{X}\end{array}$ \\
\hline $\begin{array}{l}\text { Environmental } \\
\text { Quality Assurance }\end{array}$ & & $\begin{array}{l}\text { 1Q, QAP 21-1, Quality Assurance Requirements for } \\
\text { the Collection and Eval. of Environmental Data }\end{array}$ & NA \\
\hline
\end{tabular}

EXCEPTIONS/ADDITIONS-PROCEDURES IDENTIFIED ON THE CHECKLIST WITH AN ASTERISK (*) ARE SUPPLEMENTED BY A SRNL CLARIFICATION IN L1, 8.02, “SRNL QA PROGRAM CLARIFICATIONS”. 
Revision \#0

\section{Distribution:}

F. Pennebaker, 773-A

L. M. Chandler, 773-A

M. Pitts, 704-36E

D. Gracy, 704-35E

W. Leschak, 706-8C

A. Gibbs, 704-36E

D. Cole, 704-36E

E. B. Donner, 704-56E 